\title{
PENERAPAN MEDIA E-LEARNING BERBASIS PROYEK TERHADAP KEMANDIRIAN BELAJAR DAN PEMAHAMAN KONSEP MAHASISWA UNIVERSITAS COKROAMINOTO PALOPO
}

\author{
Aswar Anas ${ }^{1}$, Nilam Permatasari Munir ${ }^{2}$ \\ Program Studi Teknik Informatika ${ }^{1}$, Universitas Cokroaminoto Palopo ${ }^{1}$, Institut \\ Agama Islam Negeri Palopo ${ }^{2}$ \\ Aswaranasspd8@gmail.com ${ }^{1}$, nilam_permatasari@iainpalopo.ac.id ${ }^{2}$
}

\begin{abstract}
Abstrak
Penelitian ini merupakan penelitian eksperimen dengan tujuan untuk mengetahui gambaran kemandirian belajar dan pemahaman konsep mahasiswa dalam penerapan E-Learning berbasis proyek dan mengetahui apakah terdapat peningkatan kemandirian belajar dan pemahaman konsep mahasiswa setelah penerapan E-Learning berbasis proyek. Penelitian ini bertempat di Universitas Cokroaminoto Palopo pada Program Studi Pendidikan Matematika dan program studi Teknik Informatika yang disetting sebagai kelas perkuliahan mata kuliah Struktur Data, Logika Informatika dan Media Pembelajaran Matematika. Hasil penelitian menunjukkan bahwa kemandirian belajar dan pemahaman konsep mahasiswa dengan penerapan E-Learning berbasis proyek jauh lebih baik jika dibandingkan dengan sebelum penerapan E-Learning. Terjadi peningkatan kemandirian belajar dan pemahaman konsep mahasiswa dengan penerapan ELearning berbasis proyek.
\end{abstract}

Kata Kunci: Media E-Learning, Kemandirian Belajar, Pemahaman Konsep

\section{A. Pendahuluan}

Tujuan dari suatu Pembelajaran adalah merubah tingkah laku dari peserta didik setelah mengikuti pembelajaran yang diberikan. Begitu pula yang terjadi dibangku perkuliahan. Dosen dalam melaksanakan perkuliahan tentunya harus memberikan perubahan yang besar kepada mahasiswa setelah mengikuti perkuliahannya. Perubahan yang dimaksud adalah terjadi penambahan dari sisi pengetahuan (kognitif), terjadinya perubahan sikap (afektif) kea rah yang ebih baik, dan terjadinya perubahan perilaku (psikomotorik) kea rah yang lebih baik pula.

Perubahan-perubahan tersebut tentunya akan tercapai jika dosen dalam menyampaikan perkuliahannya dapat memberikan pembelajaran yang tepat bagi mahasiswa. Banyak faktor yang dapat menyebabkan mahasiswa tidak dapat menerima informasi yang disampaikan oleh dosen, namun faktor yang paling berperan penting adalah penyampaian dosen harus sesuai dengan daya tangkap 
mahasiswa. Banyak yang dapat dilakukan oleh dosen agar penyampaian pembelajaran dapat diterima baik oleh mahasiswa. Salah satu cara yang sangat efektif adalah penggunaan media pembelajaran.

Menurut Mahnun (2012) Kata "media" berasal dari bahasa Latin "medium" yang berarti "perantara" atau "pengantar". Lebih lanjut, media merupakan sarana penyalur pesan atau informasi belajar yang hendak disampaikan oleh sumber pesan kepada sasaran atau penerima pesan tersebut. Penggunaan media pengajaran dapat membantu pencapaian keberhasilan belajar.

Menurut Muhson (2010) Media pembelajaran dapat merupakan wahana penyalur pesan dan informasi belajar. Media pembelajaran yang dirancang secara baik akan sangat membantu peserta didik dalam mencerna dan memahami materi pelajaran. Di era globalisasi dan informasi ini, perkembangan media pembelajaran juga semakin maju. Penggunaan Teknologi Informasi (TI) sebagai media pembelajaran sudah merupakan suatu tuntutan.

Dari beberapa alternatif yang dapat diterapkan untuk mengatasi masalah tersebut E-Learning dianggap paling mampu mencover kebutuhan mahasiswa ssat ini. E-Learning memang merupakan suatu teknologi pembelajaran yang masih tergolong baru. Untuk menyederhanakan istilah, maka electronic learning disingkat menjadi e-learning. Kata ini terdiri dari dua bagian, yaitu 'e' yang merupakan singkatan dari 'electronica' dan 'learning' yang berarti 'pembelajaran'. Jadi elearning berarti pembelajaran dengan menggunakan jasa bantuan perangkat elektronika. Menurut Arsyad (2011) E-Learning merupakan dasar dan konsekuensi logis dari perkembangan teknologi informasi dan komunikasi.

Berdasarkan uraian di atas, maka penulis mempertimbangkan melaksanakan penelitian dengan judul "Penerapan Media E-Learning berbasis Proyek terhadap Kemandirian Belajar dan Pemahaman Konsep Mahasiswa" Batasan Masalah

Untuk menghindari kemungkinan terjadinya kesalahan dalam penafsiran dan mempermudah dalam pelaksanaan penelitian di lapangan, maka penelitian ini dibatasi pada mata kuliah Struktur data, dan Logika Informatika di Universitas Cokroaminoto Palopo. 


\section{Rumusan Masalah}

Berdasarkan latar belakang masalah yang telah dikemukakan sebelumnya dan mengacu pada tujuan yang dicapai dari penelitian ini, maka dirumuskan masalah penelitian adalah:

1. Bagaimana gambaran kemandirian belajar mahasiswa dalam penerapan ELearning berbasis proyek?

2. Bagaimana gambaran pemahaman konsep mahasiswa dalam penerapan ELearning berbasis proyek?

3. Apakah terjadi peningkatan kemandirian belajar mahasiswa setelah penerapan E-Learning berbasis proyek?

4. Apakah terjadi peningkatan pemahaman konsep mahasiswa setelah penerapan E-Learning berbasis proyek?

\section{Tinjauan Pustakan}

a. Media Pembelajaran.

Media dalam prespektif pendidikan merupakan instrumen yang sangat strategis dalam ikut menentukan keberhasilan proses belajar mengajar. Sebab keberadaannya secara langsung dapat memberikan dinamika tersendiri terhadap peserta didik.

Kata media pembelajaran berasal dari bahasa latin "medius" yang secara harfiah berarti "tengah", perantara atau pengantar. Dalam bahasa Arab, media perantara atau pengantar pesan dari pengirim kepada penerima pesan.

Menurut Mahnun (2012) Para ahli membatasi pengertian media yaitu: Pertama, para ahli membatasi pengertian media dengan; orang, bahan, tekhnologi, sarana, alat, dan saluran atau berupa kegitan yang dirancang untuk terjadinya proses belajar. Kedua, para ahli membatasi pengertian media dengan; Pesan atau informasi, yang dibawa atau disampaikan melalui hardware sebagaimana tersebut di atas. Batasan ketiga, bahwa pesan yang dibawa diperuntukan sebagai merangsang terjadinya proses belajar (bahan ajar).

\section{Association for Education and Communication Technology} (AECT)mendefinisikan media yaitu segala bentuk yang dipergunakan untuk suatu proses penyaluran informasi. Sedangkan Education Association (NEA) mendefinisikan 24sebagai benda yang dapat dimanipulasi, dilihat, didengar, dibaca 
atau dibicarakan beserta instrument yang dipergunakan dengan baik dalam kegiatan belajar mengajar, dapat mempengaruhi efektifitas program instruksional.

Menurut Oemar Hamalik media pembelajaran adalah Alat, metode, dan teknik yang digunakan dalam rangka lebih mengefektifkan komunikasi dan interaksi antara guru dan siswa dalam proses pendidikan dan pengajaran di sekolah.

Dalam penelitian kali ini peneliti lebih cenderung menggunakan definisi media pembelajaran dari Oemar Hamalik dengan alasan bahwa cakupannya lebih luas, tidak hanya dibatasi sebagai alat tetapi juga teknik dan metode sehingga dapat mencakup definisi dari para ahli pendidikan lainnya.

\section{b. E-Learning}

Dari beberapa alternatif yang dapat diterapkan untuk mengatasi masalah tersebut media E-Learning dianggap paling mampu mencover kedua permasalahan tersebut. E-Learning memang merupakan suatu teknologi pembelajaran yang masih tergolong baru. Untuk menyederhanakan istilah, maka electronic learning disingkat menjadi e-learning. Kata ini terdiri dari dua bagian, yaitu 'e' yang merupakan singkatan dari 'electronica' dan 'learning' yang berarti 'pembelajaran'. Jadi elearning berarti pembelajaran dengan menggunakan jasa bantuan perangkat elektronika. Menurut Arsyad (2011) E-Learning merupakan dasar dan konsekuensi logis dari perkembangan teknologi informasi dan komunikasi.

E-Learning merupakan dasar dan konsekuensi logis dari perkembangan teknologi informasi dan komunikasi. Dimana E-Learning sebagai kegiatan belajar asynchronous melalui perangkat elektronik Komputer yang memperoleh bahan belajar yang sesuai dengan kebutuhannya.

Menurut Frame (2018) E-Learning dalam arti luas bisa mencakup pembelajaran yang dilakukan di media elektronik (Internet) baik secara formal maupun informal. E-Learning secara formal misalnya adalah pembelajaran dengan kurikulum, silabus, mata pelajaran dan tes yang telah diatur dan disusun berdasarkan jadwal yang telah disepakati pihak-pihak terkait (pengelola e-learning dan pembelajar sendiri). 
Pembelajaran seperti ini biasanya tingkat interaksinya tinggi dan diwajibkan oleh perusahaan pada karyawannya atau pembelajaran jarak jauh yang dikelola oleh universitas dan perusahaan-perusahaan (biasanya perusahaan konsultan) yang memang bergerak dibidang penyediaan jasa e-learning untuk umum.

c. Proyek

Proyek (penugasan) merupakan kegiatan pembelajaran berbasis penilaian terhadap suatu tugas yang harus diselesaikan dalam periode/waktu tertentu.Tugas tersebut berupa suatu proyek atau investigasi sejak dari perencanaan, pengumpulan data, pengorganisasian, pengolahan, dan penyajian data (Kulsum, 2011: 180). Proyek memberikan siswa suatu mekanisme untuk merencanakan, mengorganisasi, dan menciptakan suatu karya atau produk (Starkings dalam Gal\&Garfield, 1997: 140).

Masriyah (2004) menjelaskan dalam ranah ilmu matematika, pemberian tugas proyek dapat memberikan pengetahuan dan pengalaman yang lebih luas kepada peserta didik. Dalam menyelesaikan proyek, kajian ilmu matematika akan dikaitkan dengan disiplin ilmu lain dan dengan kehidupan nyata. Kegiatan-kegiatan dalam menyelesaikan proyek pada mata pelajaran matematika akan menunjukkan kepada peserta didik bahwa konsep-konsep matematika itu tidak selalu abstrak dan hanya berlaku di dalam ruang kelas saja melainkan dapat digunakan untuk kegiatan praktis yang lebih luas dalam kehidupan manusia.

\section{d. Kemandirian Belajar}

Kemandirian berasal dari kata "mandiri" ditambah dengan awalan "ke" dan akhiran "an". Konsep yang sering digunakan atau relevan dengan kemandirian adalah autonomy.

Menurut Suhendri (2011) kemandirian belajar merupakan unsur yang penting pula dalam belajar. Hal ini disebabkan sumber belajar tidak hanya berpusat pada guru. Ada sumber belajar di luar guru, seperti : lingkungan, internet, buku, pengalaman, dan lain-lain. Siswa yang memiliki kreativitas tinggi cenderung merasa tidak cukup terhadap materi pelajaran yang diperoleh dari guru. Sehingga mereka mencari informasi dari luar guru. Akibatnya pengetahuan siswa tersebut 
akan bertambah. Oleh karena itu, kemandirian belajar siswa juga sangat penting dalam kegiatan belajar matematika.

Menurut Erikson (dalam Desmita 2009 : 185) Kemandirian adalah usaha untuk melepaskan diri sendiri dari orang tua dengan maksud untuk menemukan dirinya melalui proses mencari indentitas ego, yaitu merupakan perkembangan ke arah individualitas yang mantap dan berdiri sendiri.

e. Pemahaman Konsep

Pemahaman diartikan dari kata understanding (Sumarmo, 1987). Derajat pemahaman ditentukan oleh tingkat keterkaitan suatu gagasan, prosedur atau fakta matematika dipahami secara menyeluruh jika hal-hal tersebut membentuk jaringan dengan keterkaitan yang tinggi.

Menurut NCTM (2000), untuk mencapai pemahaman yang bermakna maka pembelajaran matematika harus diarahkan pada pengembangan kemampuan koneksi matematik antar berbagai ide, memahami bagaimana ideide matematik saling terkait satu sama lain sehingga terbangun pemahaman menyeluruh, dan menggunakan matematik dalam konteks di luar matematika.

Sejalan dengan hal di atas (Depdiknas, 2003: 2) mengungkapkan bahwa, pemahaman konsep merupakan salah satu kecakapan atau kemahiran matematika yang diharapkan dapat tercapai dalam belajar matematika yaitu dengan menunjukkan pemahaman konsep matematika yang dipelajarinya, menjelaskan keterkaitan antar konsep dan mengaplikasikan konsep atau algoritma secara luwes, akurat, efisien, dan tepat dalam pemecahan masalah.

\section{B. Metode Penelitian}

Penelitian ini termasuk jenis penelitian eksperimen. Setelah diberikan perlakuan khusus yaitu diajar dengan menggunakan E-Learning, sampel diberikan angket pemahaman konsep dan kemandirian belajar.

Penelitian ini menggunakan metode eksperimen dengan hanya menggunakan tes akhir (posstest). posttest $\left(\mathrm{O}_{1}\right)$ dan $\mathrm{O}_{2}$ diadakan setelah memberikan perlakuan (X). Adapun desain dalam penelitian ini terlihat seperti pada tabel dibawah ini: 
Table.1 Desain Penelitian

\begin{tabular}{cc}
\hline Perlakuan & Posttest \\
\hline \multirow{2}{*}{$\mathrm{X}$} & $\mathrm{O}_{1}$ \\
\cline { 2 - 2 } & $\mathrm{O} 2$ \\
\hline
\end{tabular}

Sumber: Sugiyono (2008:110)

Keterangan:

X : Perlakuan pada kelas eksperimen

$\mathrm{O}_{1} \quad$ : Kemandirian belajar mahasiswa setelah diberi perlakuan (Posttest).

$\mathrm{O}_{2}$ : Pemahaman konsep mahasiswa setelah diberi perlakuan (Posttest).

Sebelum melaksanakan penelitian maka terlebih dahulu dilakukan perencanaan yang matang agar penelitian dapat berjalan dengan lancar. Hal-hal yang dilakukan pada tahap ini adalah sebagai berikut:

a. Menelaah kurikulum untuk setiap mata kuliah.

b. Mempersiapkan perangkat pembelajaran GBPP dan SAP.

c. Mempersiapkan angket pemahaman konsep mahasiswa setelah penerapan ELearning.

d. Mempersiapkan Tes Kemandirian belajar Mahasiswa.

Pelaksanaan Penelitian

a. Melaksanakan proses belajar mengajar di kelas dengan menjalankan rencana pembelajaran yang disusun sebelumnya.

b. Memberikan tes kemandirian belajar kepada mahasiswa (pretest)

c. Menerapkan Media E-Learning dalam pembelajaran di kelas.

d. Memberikan angket pemahaman konsep pada pertemuan terakhir penerapan E-Learning.

e. Memberikan tes kemandirian belajar setelah penerapan E-Learning (Posttest).

\section{Hasil dan Pembahasan}

Hasil analisis statistika deskriptif menunjukkan karakteristik distribusi skor masing-masing variabel dan sekaligus merupakan jawaban atas masalah deskriptif yang dirumuskan dalam penelitian ini.

1) Pemahaman konsep mahasiswa dengan penerapan Media E-Learning berbasis proyek.

Berikut ini adalah tabel yang berisi tentang gambaran umum pemahaman mahasiswa selama penerapan media E-learning. 
Tabel 1. Deskriptif pemahaman konsep mahasiswa

\begin{tabular}{cc}
\hline Sumber variansi & Kemandirian Belajar \\
\hline Mean & 77.5 \\
\hline Median & 77.5 \\
\hline Modus & 75 \\
\hline Standar Variansi & 11.50 \\
\hline Variansi & 132.4
\end{tabular}

Sumber: Hasil analisis data primer (2019)

Berdasarkan dari tabel 1 data Pemahaman konsep mahasiswa selama proses pembelajaran dengan menggunakan E-Learning berbasis proyek terlihat bahwa mahasiswa memiliki pemahaman konsep dalam kategori baik.

2) Kemandirian Belajar mahasiswa dengan penerapan Media E-Learning.

Berikut ini adalah tabel yang berisi tentang gambaran umum kemandirian belajar mahasiswa sebelum dan setelah penerapan media E-learning.

Tabel 2. Deskriptif kemandirian belajar mahasiswa

\begin{tabular}{cc}
\hline Sumber variansi & Kemandirian Belajar \\
\hline Mean & 95.74 \\
\hline Median & 96.5 \\
\hline Modus & 95 \\
\hline Standar Variansi & 13.91 \\
\hline Variansi & 193.4
\end{tabular}

Sumber: Hasil analisis data primer (2019)

Berdasarkan dari tabel 2 data kemandirian belajar mahasiswa selama proses pembelajaran dengan menggunakan E-Learning terlihat bahwa mahasiswa memiliki kemandirian belajar dalam kategori sangat baik.

Hasil Analisis Statistika Inferensial

Sebagai syarat untuk melakukan pengujian hipotesis, maka terlebih dahulu dilakukan uji normalitas.

a. Uji Normalitas

Pengujian normalitas data dalam penelitian ini dimaksudkan untuk mengetahui apakah data yang diteliti berasal dari populasi berdistribusi normal atau tidak. Adapun keputusan yang diambil dari output SPSS yaitu nilai signifikan dari tabel Test of Normality dikolom Kolmogorov-Smirnov dengan pedoman pengambilan keputusan adalah:

1) Kemandirian belajar Mahasiswa

Berdasarkan tabel Tests of Normality dikolom Kolmogorov-Smirnov diperoleh bahwa nilai probabilitas adalah $0,200 \geq 0,05$. Maka dapat disimpulkan bahwa data berdistribusi normal (simetris). 
2) Pemahan Konsep Mahasiswa

Berdasarkan tabel Tests of Normality dikolom Kolmogorov-Smirnov diperoleh bahwa nilai probabilitas adalah $0,10 \geq 0,05$. Maka dapat disimpulkan bahwa data berdistribusi normal (simetris).

b. Hasil Pengujian Hipotesis

1). Pemahan Knsep Mahasiswa

Uji hipotesis dianalisis dengan menggunakan uji-t (one sample t-test) untuk mengetahui Apakah rata-rata pemahan konsep mahasiswa minimal berada pada kategori tinggi.

Untuk keperluan pengujian hipotesis statistik hipotesis ini dirumuskan sebagai berikut:

$\mathrm{H}_{0}: \mu_{1}<70$ melawan $\mathrm{H}_{1}: \mu_{1} \geq 70$

Berdasarkan analisis inferensial tampak bahwa nilai $p$ (one sample test) adalah $0,0005<0,05$ dengan demikian $\mathrm{H}_{0}$ ditolak artinya terdapat peningkatan pemahaman konsep mahasiswa setelah penerapan E-Learning berbasis proyek.

2). Kemandirian Belajar Mahasiswa

Uji hipotesis dianalisis dengan menggunakan uji-t (one sample t-test) untuk mengetahui Apakah rata-rata kemandirian belajar mahasiswa minimal berada pada kategori tinggi.

Untuk keperluan pengujian hipotesis statistik hipotesis ini dirumuskan sebagai berikut:

$$
\mathrm{H}_{0}: \mu_{1}<70 \text { melawan } \mathrm{H}_{1}: \mu_{1} \geq 70
$$

Berdasarkan analisis inferensial tampak bahwa nilai $p$ (one sample test) adalah $0,0001<0,05$ dengan demikian $\mathrm{H}_{0}$ ditolak artinya terdapat peningkatan kemandirian belajar mahasiswa setelah penerapan E-Learning berbasis proyek.

Pembahasan Penelitian

\section{Analisis Statistika Deskriptif}

Pemahaman konsep mahasiswa menunjukkan dengan penerapan E-Learning berbasis proyek, pemahaman konsep mahasiswa jauh lebih baik jika dibandingkan dengan sebelum penerapan E-Learning. Terlihat rata-rata mahasiswa sebelum penerapan E-Learning hanya sebesar 55 atau hanya berada pada kategori sedang, 
namun setelah penerapan E-Learning kemandirian belajar mahasiswa meningkat dengan rata-rata 77.5 atau berada pada kategori Baik

Kemandirian belajar mahasiswa menunjukkan dengan penerapan E-Learning kemandirian belajar mahasiswa jauh lebih baik jika dibandingkan dengan sebelum penerapan E-Learning. Terlihat rata-rata mahasiswa sebelum penerapan ELearning hanya sebesar 68.26 atau hanya berada pada kategori sedang, namun setelah penerapan E-Learning kemandirian belajar mahasiswa meningkat dengan rata-rata 95.74 atau berada pada kategori sangat baik.

Analisis Statistika Inferensial

Berdasarkan data inferensial pemahaman konsep dan kemandirian belajar mahasiswa dengan menggunakan taraf signifikan 5\% diperoleh kesimpulan $\mathrm{H}_{0}$ ditolak artinya terjadi peningkatan kemandirian belajar mahasiswa dengan penerapan E-Learning berbasis proyek dan terjadi peningkatan pemahaman konsep mahasiswa setelah penerapan E-Learning berbasis proyek.

\section{Kesimpulan}

Berdasarkan hasil analisis data penelitian, dapat disimpulkan bahwa pembelajaran dengan menggunakan E-Learning sebagai berikut:

1. Pemahaman konsep mahasiswa menunjukkan dengan penerapan E-Learning berbasis proyek, pemahaman konsep mahasiswa jauh lebih baik jika dibandingkan dengan sebelum penerapan E-Learning. Terlihat rata-rata mahasiswa sebelum penerapan E-Learning hanya sebesar 55 atau hanya berada pada kategori sedang, namun setelah penerapan E-Learning kemandirian belajar mahasiswa meningkat dengan rata-rata 77.5 atau berada pada kategori Baik.

2. Kemandirian belajar mahasiswa menunjukkan dengan penerapan E-Learning kemandirian belajar mahasiswa jauh lebih baik jika dibandingkan dengan sebelum penerapan E-Learning. Terlihat rata-rata mahasiswa sebelum penerapan E-Learning hanya sebesar 68.26 atau hanya berada pada kategori sedang, namun setelah penerapan E-Learning kemandirian belajar mahasiswa meningkat dengan rata-rata 95.74 atau berada pada kategori sangat baik.

3. Terjadi peningkatan kemandirian belajar mahasiswa dengan penerapan ELearning berbasis proyek. 
4. Terjadi peningkatan pemahaman konsep mahasiswa setelah penerapan ELearning berbasis proyek.

\section{DAFTAR PUSTAKA}

Arsyad, A. (2011). Media pembelajaran.

Depdiknas. 2003. Pedoman Khusus Pengembangan Sistem Penilaian Berbasis Kompetensi SMP. Jakarta: Depdiknas.

Desmita. 2009. Psikologi Perkembangan Peserta Didik. Bandung : PT. Remaja Rosdakarya.

Hamdu, G., \& Agustina, L. (2011). Pengaruh motivasi belajar siswa terhadap prestasi belajar IPA di sekolah dasar. Jurnal penelitian pendidikan, 12(1), 90-96.

Mahnun, N. (2012). Media pembelajaran (kajian terhadap langkah-langkah pemilihan media dan implementasinya dalam pembelajaran). AnNida', 37(1), 27-34.

Muhson, A. (2010). Pengembangan media pembelajaran berbasis teknologi informasi. Jurnal Pendidikan Akuntansi Indonesia, 8(2).

National Council of Teachers of Mathematics (2000). Principles and Standars for School Mathematics. Reston, VA: NCTM.

Prasojo, R. J. (2014). Pengaruh Perhatian Orang Tua Dan Kedisiplinan Belajar Terhadap Prestasi Belajar Mata Pelajaran IPS. Ekonomi IKIP Veteran Semarang, 2(1).

Setianingsih, D. (2008). Perbedaan kedisiplinan belajar siswa ditinjau dari pola asuh orangtua (Doctoral dissertation, Universitas Muhammadiyah Surakarta).

Suhendri, H. (2011). Pengaruh kecerdasan matematis-logis dan kemandirian belajar terhadap hasil belajar matematika. Formatif: Jurnal Ilmiah Pendidikan MIPA, 1(1).

Sumarmo, U. 1987. Kemampuan Pemahaman dan Penalaran Matematik Siswa SMA Dikaitkan dengan Penalaran Logik Siswa dan Beberapa Unsur Proses Belajar Mengajar. Disertasi pada Pascasarjana IKIP Bandung: tidak diterbitkan. 